\title{
REVIEW ON THE ESTABLISHMENT OF LEGISLATION IN INDONESIA
}

\author{
Akhmad Adi Purawan* \\ Deputy of Legislation, Ministry of State Secretariat, Jakarta Pusat \\ Jalan Veteran Street No. 17 Jakarta Pusat, DKI Jakarta 10110
}

\begin{abstract}
Indonesian quality of legislation is far from perfect which indicated by the high number of judicial review. Using juridical normative methods, this study examines the causes of poor quality of legislation and the adequacy of the Law on the Establishment of Legislation to produce high quality legislation. The study found that, first, the poor quality of the legislation occurred due to the lack of elements of transparency and accountability in the formation of legislation. Second, the Law on the Establishment of Legislation is incompetence for the creation of good quality legislation due to unstructured of public participation mechanism and inscrutable process of decision-making.
\end{abstract}

Keywords: establishment of legislation, judicial review.

\section{Intisari}

Kualitas peraturan perundang-undangan Indonesia masih jauh dari sempurna yang diindikasikan dengan tingginya angka pengujian undang-undang. Dengan menggunakan metode yuridis normatif, studi ini mencari penyebab rendahnya kualitas peraturan perundang-undangan dan kemampuan Undang-Undang tentang Pembentukan Peraturan Perundang-undangan untuk menghasilkan peraturan perundang-undangan yang berkualitas. Studi ini menemukan bahwa, pertama, rendahnya kualitas peraturan perundang-undangan disebabkan belum dipenuhinya unsur transparansi dan akuntabilitas dalam pembentukan peraturan perundang-undangan. Kedua, Undang-Undang tentang Pembentukan Peraturan Perundang-undangan masih belum mampu menghasilkan peraturan perundang-undangan yang berkualitas karena tidak terstrukturnya pengaturan mengenai partisipasi publik dan tidak dapat ditelusurinya proses pengambilan keputusan.

Kata Kunci: pembentukan peraturan perundang-undangan, pengujian undang-undang.

\section{Pokok Muatan}

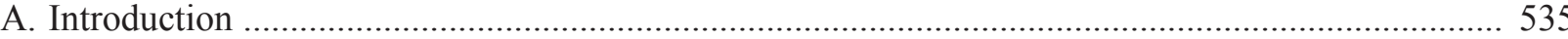

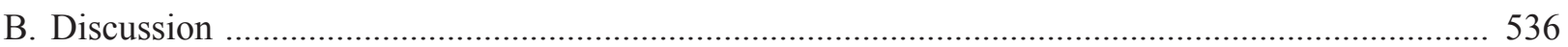

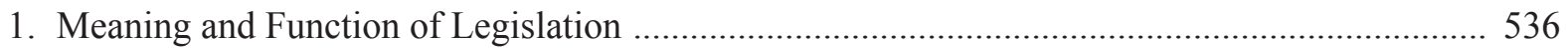

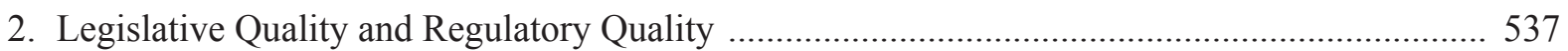

3. Ensuring Standard on the Law of the Establishment of Legislation ......................................... 538

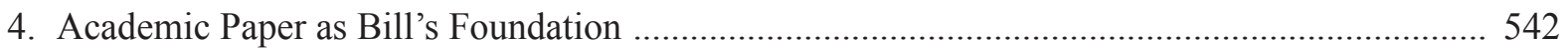

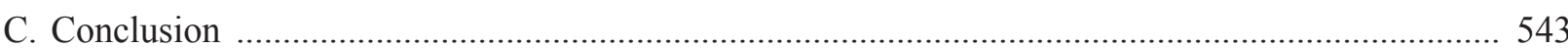

Correspondence address: akhmad_adi@setneg.go.id 


\section{A. Introduction}

The 1945 Constitution of the Republic of Indonesia stated that Indonesia is a state based on rule of law. This principle presupposes that every element of the state, either executives or legislatives and judicative and the people shall base any behaviour by law. The democratic state based on rule of law perceive two important principles: the principle of legitimacy (the democratic principle of legitimacy) and the principle of legality (the rule of law principle of legality). ${ }^{1}$ The principle of legitimacy requires that the legal norms, laws and regulations that are binding for the people, must be born from community representatives who are elected democratically. The principle of legality requires that government powers is limited by law and its action need a basis in the law, in any case, as far as these actions unilaterally impose legal obligation for citizens, reduce the constitutional rights of citizens, or affect the rights.

As rule of law state based, all aspects of life should be included based on the law. In a narrow sense, the law is often interpreted as legislation. Legislation is written rule that contains binding legal norms which formed or established by state agencies or officials authorized by established procedures. There are two inherent nature of the understanding, i.e. formal and material. The formal nature determines that the legislation created or determined by a state agency or authorized officials through established procedures. Material properties determine that the legislation contains binding legal norms.

In order to materialize Indonesia as rule of law state based, President and DPR has set Law No. 10 of 2004 on the Establishment of Legislation which governing principles, procedures, and techniques of formation of legislation. It was formed to meet the provisions of Art. 22A of the 1945 Constitution and Art. 6 of MPR Decree No. III/MPR/2000 on Sources of Law and Hierarchy of Laws. Long before it, Indonesia has law making legislation in the form of law and president decree, ${ }^{2}$ but because of Constitutional reform of 1999 to 2002, particularly Art. 20 par. (1) which provides that the House holds the power to make law, then those various laws and regulations are no longer valid. Law No. 10 of 2004 can be said to be a masterpiece of Indonesian law system. This law is a comprehensive document that contains a description of the process of making laws that bind all state institutions and government agencies. In 2011, Law no. 10 of 2004 was replaced by Law No. 12 of $2011 .^{3}$

However, after ten years of enactment of the Law No. 10 of 2004 which then superseded by Law No. 12 of 2011, law making are not going well. One of indications is the high number of judicial review cases tried by Mahkamah Konstitusi. Since it

Jan A.B. Janus, 2013, A Compilation of Introductions on Legislation in the Netherlands, ROM B.V., The Hague, p. 16.

Law No. 10 of 2004 on the Establishment of Laws and Regulations revoked a number of other legal instruments including:

- $\quad$ Algemeene Bepalingen van Wetgeving voor Indonesie (Stb. 1847: 23) on General Laws and Regulations.

- Law No. 1 of 1950 on the Types and Forms of National Government Regulations (Peraturan tentang Jenis dan Bentuk Peraturan yang Dikeluarkan oleh Pemerintah Pusat).

- Law No. 2 of 1950 on Establishing Emergency Laws on Publishing the Government Gazette of the United States of Indonesia and the Issuance, Promulgation and Implementation of Federal Laws and Government Regulations as Federal Laws (Menetapkan UndangUndang Darurat tentang Penerbitan Lembaran Negara Republik Indonesia Serikat dan Berita Negara Republik Indonesia Serikat dan tentang Mengeluarkan, Mengumumkan dan Mulai Berlakunya Undang-Undang Federal dan Peraturan Pemerintah sebagai UndangUndang Federal).

- Government Regulation No. 1 of 1945 on the Promulgation and Implementation of Laws and Government Regulations (Pengumuman dan Mulai Berlakunya Undang-Undang dan Peraturan Pemerintah).

- Presidential Decision No. 234 of 1960 on Returning the State Legislation Section from the Ministry of Justice to the State Secretariat (Pengembalian Seksi Pengundangan Lembaran Negara dari Departemen Kehakiman ke Sekretariat Negara).

- Presidential Instruction No. 15 of 1970 on the Preparation of Proposed Bills and Draft Government Regulations (Tata Cara Mempersiapkan Rancangan Undang-Undang dan Rancangan Peraturan Pemerintah Republik Indonesia).

Presidential Decree No. 188 of 1998 on the Preparation of Proposed Bills (Tata Cara Mempersiapkan Rancangan Undang-Undang).

- Presidential Decree No. 44 of 1999 on the Technique to Prepare Laws and Government Regulations and the Form of Proposed Bills, Draft Government Regulations and Draft Presidential Decrees (Teknik Penyusunan Peraturan Perundang-undangan dan Bentuk Rancangan Undang-Undang, Rancangan Peraturan Pemerintah dan Rancangan Keputusan Presiden).

Law Number 12 of 2011 on Reformulation of Statutory Law made some improvement on legislative drafting technique, hierarchy of legislation, regulation planning and mandatory academic studies as ex ante assessment of regulatory proposal. 
established in 2003, Mahkamah has been reviewing 233 laws against the Constitution in which 140 cases have been granted. ${ }^{4}$ The number of trials increases every year as shows in the figure 1. Many of those laws have been challenge by the public to the Court even within a day and several days after the enactment. Constitutional Justice argue that poor quality of legislation is the reason of judicial review escalation. ${ }^{5}$ If that is the case, then there are problems in the formation of legislation.

\section{Figure 1. Judicial Review Application}

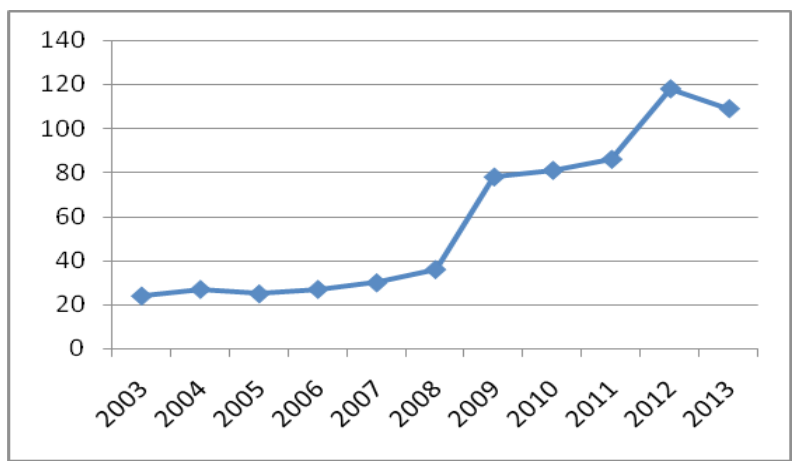

Source: Mahkamah Konstitusi, 2014.

Many factors led to the formation of legislation to be imperfect. Otto, Stoter, and Arnscheidt stated that there are two major problems in the formation of legislation in developing countries. The first problem relates to the role and legitimacy of lawmakers and law-making procedure itself. The second problem relates to the effectiveness of law in society. ${ }^{6}$ Given the role of the Law of the Establishment of Legislation as a guide book in the form of legislation, then there are some issues that need to be studied. First, what are the causes of poor quality of legislation? Secondly, whether the Law No. 12 of 2011 on the Establishment of Legislation is adequate to produce high quality legislation?

\section{B. Discussion}

\section{Meaning and Function of Legislation}

In a narrow sense, the law is often interpreted as legislation. Legislation is a written regulation established by state institutions or authorized officials and is publicly binding. Legislation has two meanings, the first refers to the process in this case the process of formation of legislation; the second refers to the product in the form of legislation. Legislation as a product is not a single concept, but plural. As indicated in its name, it is a collected understanding which also included various types of legislation, ranging from the highest to the lowest. Similarly, as a process, the formation of various types of legislation has their own process that is in some ways different between the types of rules with one another.

Considering the complexity of the formation, then what is actually a function of the legislation? This question is often asked and the answers of course vary. Kelsen argue that law is one of social techniques which are inducing the individual, by a specific means, to avoid from compulsion interference in the formation of interest of others: in case of such interference, the legal community behaves with such interference in the formation of interest of individual responsible for the previous interference. ${ }^{7}$ Continuing Kelsen's idea, Summers identify five basic techniques to response to the question of how law can help discharge social functions, which are, the grievance-remedial techniques for resolving dispute claims to remedies for grievance, the penal techniques for prohibiting misconduct, detecting violations and resolving dispute over penal liability and the punishment, the administrative-regulatory technique for preventive measure to assure regulates comply with regulatory standard, the public benefit conferral technique for

\footnotetext{
See Mahkamah Konstitusi, "Rekapitulasi Perkara Pengujian Undang-Undang", http://www.mahkamahkonstitusi.go.id/index.php?page=web. RekapPUU, accessed on August 7, 2014.

See The Jakarta Post, "Judicial Review "Reflect Poor-Quality Laws" http://www.thejakartapost.com/news/2010/08/18/judicial-reviews$\%$ E2\%80\%98reflect-poorquality-laws\%E2\%80\%99.html, accessed on August 72014.

6 J.M. Otto, W.S.R. Stoter, J. Arnscheidt, J., "Using legislative Theory to Improve Law and Development Projects", RegelMaat afl. 2004/4, pp. 121-135.

H. Kelsen, "Law as a Specific Social Technique", 9 U.Chi. L. Rev. 75, 1941 pp. 75-97. See also Summers, R.S., "The Technique Element in Law", California Law Review, Vol. 59, Issue 3, 1971, pp. 733-751.
} 
conferring upon individual governmental benefits, such as education, health programs, and welfare payments, and the private arranging technique for facilitating and effectuating private arrangements. ${ }^{8}$

What is argue by Kelsen and Summers are the most fundamental function of legislation which is enabling government to intervene in markets, social or political life (instrumental function). However, it does not stop to there. Voermans stated that legislation has less well known but important non-instrumental functions i.e. to establish a certain government agency, the division of authority and restrictions on government action (constitutional function), the middle path over the political interests conflicting (political function), community involvementin government, and hence the legitimacy of the government as well as a tool to regulate society (democratic function), communicating and ensuring the existence of public morals, values, and the lives of many people (symbolic function), and set and put the implementation of the authority of the government agencies (bureaucratic function). ${ }^{9}$

\section{Legislative Quality and Regulatory Quality}

In recent years many studies of international institutions concerns about quality of Indonesian legislation. However, most of these studies focus on 'regulatory quality' compared to the 'legislative quality'. For example, a study conducted by the OECD about review of regulatory reform in Indonesia which aims to assist the Indonesian government in its effort to improve the quality of legislation in order to support the interests of business and public, attracting investment, improving public services and welfare. ${ }^{10}$ Studies that conducted by the World Bank when measuring governance indicators are also using regulatory quality as one of the dimensions measured, instead of legislative quality. ${ }^{11}$

Regulatory quality and legislative quality are different concepts. The regulatory quality is the extent to which legislation, as an instrument of public policy, permits and promotes private sector development, while quality of legislation is the extent to which the criteria, emanating from constitutional principles, are met. ${ }^{12}$ Improving legislative quality may require a different approach than the improvement of regulatory quality. Since legislative quality standards can only emanate from constitutional principles, the only right measure for the quality of legislation is its ability express law. ${ }^{13}$ Meanwhile, regulatory quality can be measured by its successful in implementing policies to permit and promote private sector development, fair market conditions, stable institutions or citizens' satisfaction. To measure the achievement of regulatory quality requires public policy analysis, while achieving legislative quality can be measured from the standards laid down in the directives of legislation.

The different notions are not mutually exclusive; in fact they coincide in some respects. However, the differences between the regulatory and legislative quality can be measured at the functions attributed to the legislation. ${ }^{14}$ Regulatory quality deal with legislative functions as instrument of public policy in which government enable to intervene in markets, social or political life (instrumental function), while legislative quality deal with more in particular constitutional function

\footnotetext{
R.S. Summers, Op.cit., p. 7.

Wim Voermans, "Concern about the Quality of EU Legislation: What Kind of Problem, by What Kind of Standards?", Erasmus Law Review, Vol. 02, Issue 01, 2009, pp. 59-95.

10 See OECD, 2009, OECD Reviews of Regulatory Reform in Indonesia, Government Capacity to Assure High Quality Regulation, OECD, Paris, p. 6 .

11 See Kaufman, D., Kraay, A., Mastruzzi, M., “Governance Matters VI: Aggregate and Individual Governance Indicators 1996 - 2006 ”, World Bank Policy Working Paper 4280, July 2007, p. 4.

Wim Voermans, Op.cit., p. 9.

Ibid.

Ballin, Ernst M.H. Hirsch and Linda A.J. Senden, 2005, Co-Actorship in the Development of European Law-Making: the Quality of European Legislation and Its Implementation and Application in the National Legal Order, T.M.C. Asser Press, The Hague on Wim Voermans, The Netherlands, p. 8.
} 
and symbolic function. ${ }^{15}$

\section{Ensuring Standard on the Law of the Establishment of Legislation}

Law No. 10 of 2004 and Law No. 12 of 2011 on the Establishment of Legislation is Indonesian standard of legislation which guaranteed both legislative quality and regulatory quality. In general, the process of a legislation has to pass at least three corridor: administrative corridor, academic corridor and political corridors. ${ }^{16}$ Administrative corridor requires the compliance of the law making provisions; academic corridor requires that legislation should be accountable academically; where political corridors requires that legislation are established through political institutions which able to absorb and in line with the aspirations of the public in substance.

This study found that the notion of administrative, academic and political corridors are shown by their compliance of legislative principles, formation stages and drafting techniques and the existence of an academic paper.

\section{a. Legislative Principles}

Either Law No. 10 of 2004 or Law No. 12 of 2011 laid down seven formal principles of good regulation formation and ten material principles of legislation. The formal principles covers clarity of purpose, the right institution or establishing organ, the fit between types, hierarchies, and material content, executable, efficiency and effectiveness, formulation clarity and transparency, while material principles covers the principles of security, humanitarian, nationality, kinship, kenusantaraan (nation-statehood), unity in diversity, justice, equality before the law, rule of law, as well as balance and harmony.

However, this study found that inclusion of the good regulation formation principles is not original, but it has been adopted from the writings of I.C. van der Vlies in Handboek Wetgeving (1991). ${ }^{17}$ In her book, I.C. van der Vlies describes in detail the principles of the formation of legislation that is either derived from the suggestions of the Raad van State (Council of State) before an act of parliament submitted to the Staten General (parliament) or the discussion documents act of parliament in Staten General, court, directive of legislation and the simplification of legislation commission's final report. The principles are arranged as fruit of constitutional practice prevailing in the Netherlands that it adopted in Indonesian law making statute. Unfortunately, this study found that the adoption of such principles is not completely elaborated in the legislative drafting technique.

The legislative drafting technique is annex of the Law. The annex have role as directives for legislative drafter and legislation framer. In connection with the preparation of technical legislation, the study found that the technique of preparation of the legislation can only partially accommodate the principles such as clarity of purpose, the right institution or establishing organ, the fit between types, hierarchies, and material content and clarity of formulation, while the rest of the principle i.e. executable, efficiency and effectiveness and transparency is remain silent. The adoption of foreign values in the legislation is often done in many regulations. However, because of the principles set forth in both law are the fruit of constitutional practice in the Netherlands, these principles ought to be elaborate further in the legislative drafting technique.

16 Yusril Ihza Mahendra, "Bahan Penjelasan Menteri Sekretaris Negara pada Rapat Kerja dengan Komisi II DPR RI tanggal 25 Januari 2006", Rapat Kerja Menteri Sekretaris Negara - Komisi II DPR RI, Jakarta, January 25, 2006.

17 See Introductory of Legislative Drafter Handbook of Direktorat Jenderal Peraturan Perundang-undangan Departemen Hukum dan Hak Asasi Manusia RI, 2005, Buku Pegangan Perancang Peraturan Perundang-undangan, Direktorat Jenderal Peraturan Perundang-Undangan Departemen Hukum dan Hak Asasi Manusia RI, Jakarta, p. iii. 


\section{b. Legislative Procedure and Drafting Technique}

The process of law making, according to the synoptic policy-phases theory, ${ }^{18}$ as a process that is supposed well organized and focused on the form of a binding decision which aims to provide direction for the community as a whole. According to the theory, the policy developed under the auspices of the institutions that are politically accountable, each of which has its own role in which political actors are the ones who are responsible for determining the content of the law that is to be formed. However, this study found that in reality the formation of legislation in Indonesia is not the case. An imperfection processes occur at almost every stage of the formation of legislation, ranging from planning, preparation, until the discussion.

\section{c. Planning}

Law No. 10 of 2004 and Law No. 12 of 2011 use the National Legislation Program (Prolegnas) as instruments for drafting legislation. Prolegnas is prepared by the Parliament and the Government. The goal is creating national legal system. To meet these objectives, Prolegnas has been set up to medium-term (5 years) and annual priorities. Prolegnas contains a bill title, regulated materials, and links with other legislation. List of the bill are based on the order of the constitution, MPR commands, commands other laws, national development planning system, as well as the aspirations and needs of the community. Prolegnas is prepared by joint committee of DPR and President. Prolegnas is enacted by the DPR Decree.
Prolegnas has a very vital role in the formation of legislation. In the micro-scope, Prolegnas not just be "entry ticket" for any bill to be formed, but also became the foundation for the formation of the bill itself. While the macro level, Prolegnas be a measuring instrument of achieving the development goals of national law which the end goal is the embodiment of the national legal system. However, this study found that from the two periods Prolegnas medium term (2005-2009 and 2010-2014), Prolegnas are still far from expectations. Although Prolegnas addresses vision and mission, goals and policy direction, however we cannot see the nexus with the bill list since the list is only a list of titles without any explanation of the subject matter of the legislation. This findings are in line with Indrati's conclusion. ${ }^{19}$

Law No. 10 of 2004 does not describe in detail about the Prolegnas form. Its detail has been govern by President Decree No. 61 of 2005 on Procedures for Preparation and Prolegnas Management. The Decree set that Prolegnas include title of bills along with its subject matter and association with other legislation. The subject matter consists of description about background and purpose, target to be achieved, and its range and direction setting policy. Unfortunately, what has been set out in the Decree are not shown at two predetermined Prolegnas which lead to vagueness of legal development in Indonesia. However, provisions of Presidential Decree No. 61 of 2005 have been adopted in the Law No. 12 of 2011. The Law even determined that subject matter of each bills has to become basic foundation of the academic paper. ${ }^{20}$

A. Hoogerwerf, 1992, Het ontwerpen van beleid, Samson H.D. Tjeenk Willink, Alphen a/d Rijn; Charles E. Lindbolm, 'The Science of Muddling Through', Public Administration Review, 2/1959: S. 79-88 in J.M. Otto, W.S.R. Stoter, J. Arnscheidt, Op.cit., p. 5.

19 See Maria Farida Indrati, 2007, Ilmu Perundang-Undangan II, Proses dan Teknik Pembentukannya, Penerbit Kanisius, Yogyakarta, pp. 48-78.

20 See Art. 19 paragraph (3) Law No. 12 of 2011 on Reformulation of Statutory Law (State Gazette of the Republic Indonesia Number 82 of 2011, Supplement to State Gazette of the Republic Indonesia Number 5234). 
Beside the substance of Prolegnas, this study found inaccuracy of the planning as indicated from the large disparity in the amount of the bill is that planned and its realization. This study noted that among 284 bill list on Prolegnas 2005-2009 out of bill ratification of the treaty, the bill as a result of the decision of the Constitutional Court, the state budget bill, the bills of provincial/regency/ city, provisional law approvement (open-list bills) only 85 bill has been discussed and enacted. As for Prolegnas 2010-2014, from 247 bills out of open-list bills, until the end of 2013 only 43 bill that had been discussed and enacted (Table 1). In respect of the data, many people blame on the low performance of the DPR in the legislation. However, this study propose another thesis that it is caused by inadequacy to make specific, measurable, achievable, realistic and time based planning. From the trend, it conclude that the ability on producing legislation is about 30 bills per year, in fact Prolegnas always set 70 . This study suggest that DPR and President have to seek the way to solve this problem by treating Prolegnas as not list of the wishes but list of needs to develop Indonesian legal system.

Tabel 1. Bills Has Been Discussed and Enacted

\begin{tabular}{|c|c|c|c|c|c|c|c|c|c|c|c|}
\hline \multirow{2}{*}{\multicolumn{2}{|c|}{ Bills }} & \multicolumn{5}{|c|}{ Prolegnas 2005-2009 } & \multicolumn{5}{|c|}{ Prolegnas 2010-2014 } \\
\hline & & 2005 & 2006 & 2007 & 2008 & 2009 & 2010 & 2011 & 2012 & 2013 & 2014 \\
\hline \multicolumn{2}{|c|}{ Priority Bills } & 6 & 11 & 14 & 19 & 35 & 6 & 19 & 10 & 8 & n.a \\
\hline \multirow{6}{*}{$\begin{array}{l}\text { open } \\
\text { list } \\
\text { bills }\end{array}$} & ratification of the treaty & 2 & 7 & 4 & 3 & 5 & 2 & 1 & 6 & 2 & n.a \\
\hline & implementing the & - & - & - & - & 1 & - & 1 & - & 1 & n.a \\
\hline & $\begin{array}{l}\text { Constitutional Court } \\
\text { decision }\end{array}$ & & & & & & & & & & \\
\hline & state budget & 3 & 4 & 3 & 2 & 4 & 4 & 3 & 3 & 3 & n.a \\
\hline & $\begin{array}{l}\text { provincial/regencyt/city } \\
\text { formation }\end{array}$ & - & - & 25 & 31 & 2 & - & - & 5 & 10 & n.a \\
\hline & $\begin{array}{l}\text { provisional law's } \\
\text { approvement }\end{array}$ & 3 & 1 & 2 & 1 & 6 & 1 & - & - & - & n.a \\
\hline \multicolumn{2}{|c|}{ Total (Realization) } & 14 & 23 & 48 & 56 & 52 & 13 & 24 & 24 & 24 & n.a \\
\hline \multicolumn{2}{|c|}{ Prolegnas (Planning) } & 55 & 45 & 80 & 79 & 76 & 58 & 91 & 64 & 70 & \\
\hline
\end{tabular}

Source: Author's Calculations based on Deputy for Legislation Performance Report in the Ministry of State Secretariat.

\section{d. Preparation}

The bill can be derived from the DPR/ DPD or the President. The bill proposed by DPR submitted by a member, a commission, a joint committee, or special legislative body, while the bill submitted by the President prepared by the minister/head of non-ministerial government agencies. Both should be harmonizing. Harmonization of the House's bill made by the special body under the House, while the bill of the President conducted by the Ministry of Justice and Human Rights. After going through this stage, the bill is discussed further between relevant commission and ministers appointed to represent the President in the discussion.

The process of bill formation requires plenty of time. In respect of government initiative, the duration of the process of formation not only in the discussion in parliament, but also at the time of its formation in the inter-ministerial committee. This study found that although the government is counted as one organ of power, but in reality the parts vary. What often happen is fighting among agencies. Variations in field assignments and 
the span of control of each ministry/agency emerges sectoral ego whenever there is a draft of legislation. Each ministry/agency seeks to bring the substance covered in the span of their respective authorities. As illustrated in the bureau-political theory, ${ }^{21}$ a government policy such as the above is only an administrative competition with centrifugal force in interministerial team. According to this theory, the policy contained in the legislation was not formed on the basis of the formation of a rational or community driven process, but only the seizure of authority among government agencies.

Formulation of policies which is taken based on sectoral interests adversely affects to the quality of the established legislation. The most noticeable events exemplified in the licensing policy. According to Doing Business in Indonesia in 2012, the World Bank reports that to carry out business activities in Indonesia, businesses men must pocket 9 types of licensing form different agencies, compare with the average APEC countries which only 6 licensing, Malaysia 4 licensing, and South Korea 3 licensing. ${ }^{22}$ That many types of licensing seems to accommodate different authorities of each agencies. As the result, its gives rise to compliance costs for business and other group, leads to unnecessary complexity and associated uncertainty and reduces the ability of government to achieve its objective. Its poor regulation simply add red tape that contributes nothing useful to the economy.

\section{e. Discussion}

Discussion of the bill made by the DPR and the President or the minister assigned. Discussion is done through two level talks, namely the first-level talks in committee meetings, and the second-level talks in the plenary session. In the first-level talks, the initiator of the bill, the House or the President or the minister addresses an explanation about the bill-filed. While, the other parties then agreed to submit their views on whether or not the proposed bill to be continued to the discussion. ${ }^{23}$ If approved, it followed by a discussion of the list of inventory problem (Daftar Inventarisasi Masalah) were prepared by a party who is not the initiator of the bill. Finally, the discussion concludes with the delivery of President and party's final opinion of the bill. A second-level talk in the plenary meeting preceded the statement of approval or rejection of each party within the House and the delivery of the final opinion of the President.

This study found that establishment of legislation is the result of a process that is not simple. The formation of legislation is a complex process of transformation and exhausting in which there are many actors and different factors, each of which has a role that cannot be ignored. Although members of parliament representing people, but in the discussion of the bill, lawmakers are not the sole actor since the discussion of bill is also influenced by the insistence of civil society and mass media. Not infrequently, the bill is in conflict with the public will be discontinued. Even if the bill is eventually approved jointly by the parliament and the government, civil society remains to test the validity of

21 U. Rosenthal, "Bureaupolitiek en Bureaupolitism: om het Behoud van een Competitief Overheidsbestel (oraties Leiden)", in Samson H.D. Tjeenk Willink, et al., Alphen a/d Rijn; G.T. Allison, 1971, Essence of Decision: Explaining the Cuban Missile Crisis, Little, Brown \& Co, Boston. See also M. Scott-Tanner, "How a Bill Becomes a Law in China: Stages and Process in Law Making", in St. Lubman (Ed.) 1996, China's Legal Reforms, Oxford University Press, Oxford. See also M. Scott-Tanner, 1999, The Politics of Law Making in China: Institutions, Processes, and Democratic Prospects in Post-Mao China, Oxford University Press, Oxford on J.M. Otto, W.S.R. Stoter, J. Arnscheidt, Op.cit., p. 5 .

22 See World Bank, 2012, Doing Business in Indonesia 2012, the World Bank Group, Washington DC, p. 16.

23 Some of the bill that had been denied by the Government to be discussed include: (1) Bill on State Finance (2007), which includes the financial management of state autonomy by any state agency, (2) Bill on Regional Development Acceleration Islands (2012) because it is contrary to the Constitution 1945 and potentially violate the applicable provisions of the United Nations Convention on the law of the Sea (UNCLOS) 1982 on the law of the sea. 
the established law in the Constitutional Court. Therefore, it is understandable if the Constitutional Court since the inception of the authority to test the law, the number of test cases is very high, because every person has enough reason to examine the bill as opposed to the right of constitutionality.

Reflecting on this fact, it has become a necessity if the model of decision-making in the discussion of the bill should accommodate public participation. This study found that although Law No. 12 of 2011 is far more detailed set of community participation in the formation of legislation than the Act No. 10 of 2004, but still, the setting is still vague. Law No. 12 of 2011 stipulates that individual or group of people who have an interest in the substance of the draft entitled to oral or written input through public hearings, working visits, socialization, seminars/ workshops/discussions, but to what extent and how the mechanism are not regulated. Under its terms, the public participation is "right", so of course the community's rights can only be executed if there is the will of lawmaker to implement a public hearing and such.

Since Law No. 12 of 2011 states that the principle of transparency as one of the principles that must be followed, it has to give burden to the lawmaker to organize activities that can accommodate public participation as part of the procedure of the establishment. In Netherlands, for example since 2009 has implemented internet-based consultation or public consultation via the internet. In this case, the Ministry of Justice will publish a draft act of parliament which was compiled (along with information about the implications of regulation) in the webpage for
12 weeks where everyone may give an input on the publication in question. ${ }^{24}$ The same practices could be found in Australia, Canada, Denmark, and the United Kingdom which can be regarded as the leaders in the field of online consultation. ${ }^{25}$ Although in Indonesia does not need to replicate exactly as was done in the Netherlands and those countries, in essence, Indonesia need to consider the existence of stages of consultation/public examination of the draft prepared.

\section{Academic Paper as Bill's Foundation}

One of the most important things of the Law No. 12 of 2011 is setting an academic paper as a requirement for bill preparation since Law No. 10 of 2004 does not explicitly addressing academic paper. However, academic paper is not new in the formation of laws and regulations in Indonesia. Presidential Decree No. 188 of 1998 on Bills Formation Procedures called such thing as 'academic draft'. After the enactment of Law No. 10 of 2004, Presidential Decree No. 68 of 2005 on Procedures for Preparing RUU, RPerpu, RPP, and RPPerpres stated that initiator of a bill may precede an academic paper. Through Law No. 12 of 2011, academic papers become compulsory.

Annex I of the Law No. 12 of 2011 stated that academic paper is being equally the result of legal study and other scientific research to particular problem of subject matter of the bill, as a solution to the problems and needs of the community. There are two methodology of legal research that has set up, which are juridical normative and empirical methods. In the empirical methods (or it often called as socio-legal studies), research begins with a review of normative research or legislation, and then followed by a deep observation and dissemination of questionnaires to obtain data related non-law factors that influence observed-legislation. ${ }^{26}$ The normative method is done through examining the

\footnotetext{
See OECD, 2009, OECD Reviews of Better Regulation in the Netherlands, OECD, Paris, p. 64.

Jan A.B. Janus, Op.cit., p. 112.

Annex No. 1 of Law Number 12 of 2011 on Reformulation of Statutory Law (State Gazette of the Republic Indonesia Number 82 of 2011 , Supplement to State Gazette of the Republic Indonesia Number 5234).
} 
literature which is secondary data in the form of legislation, court decisions, agreements, contracts, or other legal documents, as well as research results, outcomes assessment, and other references. Normative methods can be supplemented with interviews, discussion (focus group discussion), and a hearing. ${ }^{27}$

Unfortunately, either Law No. 12 of 2011 or DPR's parliamentary regulations ${ }^{28}$ does not integrate of the results published in academic paper in the decision-making process within bill's discussion stage. In the discussion stage, both only to dwell on the formulation of the bill article by article. Assumptions built and the results published in the academic paper were never tested. Therefore, it is not wrong if it was thought that the existence of an academic paper is merely to fulfil the formality of filing a bill.

This study suggest that as a policy paper, academic paper should previously be discussed by the Parliament and the Government so that both institutions have the same idea over the bill to be realized. Such mechanism is not only beneficial for reducing distortion during bill discussion which created ambiguity of the result law, but also speed up the completion of the bill. Furthermore, academic papers that have been discussed may be used as an 'explanatory memorandum' that may be read by everyone, so that, for example, it is understandable why the lawmaker taking the policy. Policies are decided by rational considerations and accountable certainly reduce friction with other stakeholders who consider his constitutional rights "disturbed" over the enactment of a law. Even if it should happen, without eliminating the element of independence of judges, constitutional judges may use the above academic paper that was tested as a consideration in making the decision.

\section{Conclusion}

From the above description and the study can be summarized as follows. First, the poor quality of the legislation has not fulfilled due to the element of transparency and accountability in the formation of legislation. Transparency with regard to the regulation of the formation of legislation that has not been optimal set of public participation, while accountability with regard to the role and behaviour of institutional forming legislation that is still struggling on sectoral ego trap. Second, the enactment of Law No. 12 of 2011, which suppose be able to improve the weaknesses in the Law No. 10 of 2004 was still not sufficient for the creation of good quality legislation. The weaknesses that is highly correlated with poor quality of legislation produced, including, (1) public participation is not treated as prerequisite and formation stage of legislation, and (2) the absence of integrative discussion of the academic paper in the process of decision-making within bill's discussion stage that led to the absence of accountability in the established legislation.

\section{REFERENCES}

\section{A. Books}

Ballin, Ernst M.H. Hirsch and Linda A.J. Senden, 2005, Co-Actorship in the Development of European Law-Making: the Quality of European Legislation and Its Implementation and Application in the National Legal Order, T.M.C. Asser Press, The Hague on Wim Voermans, The Netherlands.
Direktorat Jenderal Peraturan Perundang-undangan Departemen Hukum dan Hak Asasi Manusia RI, 2005, Buku Pegangan Perancang Peraturan Perundang-undangan, Direktorat Jenderal Peraturan Perundang-Undangan Departemen Hukum dan Hak Asasi Manusia RI, Jakarta.

Indrati, Maria Farida, 2007, Ilmu Perundang- 
undangan II, Proses dan Teknik Pembentukannya, Penerbit Kanisius, Yogyakarta.

Janus, Jan A.B., 2013, A Compilation of Introductions on Legislation in the Netherlands, ROM B.V., The Hague.

OECD, 2009, OECD Reviews of Better Regulation in the Netherlands, OECD, Paris.

OECD, 2012, OECD Reviews of Regulatory Reform in Indonesia: Government Capacity to Assure High Quality Regulation, OECD, Paris.

Scott, M. and Tanner, 1999, The Politics of Law Making in China: Institutions, Processes, and Democratic Prospects in Post-Mao China, Oxford University Press, Oxford.

World Bank, 2012, Doing Business in Indonesia 2012, The World Bank Group, Washington DC.

\section{B. Journal Articles}

H. Kelsen, Law as a Specific Social Technique, 9 U.Chi. L. Rev. 75, 1941.

Hoogerwerf, A., 1992, Het ontwerpen van beleid, Samson H.D. Tjeenk Willink, Alphen a/d Rijn; Charles E. Lindbolm, "The Science of Muddling Through", Public Administration Review, 2/1959: S.

J.M. Otto, et al., "Using Legislative Theory to Improve Law and Development Projects", RegelMaat afl. 2004/4.

Summers, R.S., "The Technique Element in Law", California Law Review Vol. 59, Issue 3, 1971.

Wim Voermans, "Concern about the Quality of EU Legislation: What Kind of Problem, by What Kind of Standards?", Erasmus Law Review, Vol. 02, Issue 01, 2009.

\section{Internet Articles}

Mahkamah Konstitusi, "Rekapitulasi Perkara Pengujian Undang-Undang”, http:// www.mahkamahkonstitusi.go.id/index. php?page $=$ web.RekapPUU, accessed on August 7, 2014.

The Jakarta Post, "Judicial Review 'Reflect Poor-
Quality Laws"" http://www.thejakartapost. com/news/2010/08/18/judicial-reviews$\%$ E $2 \% 80 \% 98$ reflect-poorqualitylaws $\% E 2 \% 80 \% 99$.html, accessed on August 7, 2014.

\section{Papers}

Kaufman, et al., "Governance Matters VI:Aggregate and Individual Governance Indicators 1996 2006", Paper, World Bank Policy Working Paper 4280, July 2007.

\section{E. Articles in Anthology with Editor}

Rosenthal, U., 1988, Bureaupolitiek en Bureaupolitism: om het Behoud van een Competitief Overheidsbestel (oraties Leiden) in Willink, Samson H.D. Tjeenk, et al., a/d Rijn; G.T. Allison, 1971, Essence of Decision: Explaining the Cuban Missile Crisis, Little, Brown \& Co, Boston.

M. Scott-Tanner, "How a Bill Becomes a Law in China: Stages and Process in Lawmaking", in St. Lubman (Ed.) 1996, China's Legal Reforms, Oxford University Press, Oxford.

\section{F. Regulations}

Annex No. 1 of Law No. 12 of 2011 on reformulation of statutory law (State Gezette of The Republic Indonesia No. 82 of 2011, Supplement of State Gazette of The Republic Indonesia No. 5234).

DPR Regulation No. 01/DPR RI/2009-2010 on Parliamentary Regulations.

Law No. 10 of 2004 on the Establishment of Laws and Regulations (State Gazette of the Republic of Indonesia Number 53 of 2004, Supplement to State Gazette of the Republic of Indonesia Number 4389).

Law No. 12 of 2011 on reformulation of statutory law (State Gazette of the Republic of Indonesia Number 82 of 2011, Supplement to State Gazette of the Republic of Indonesia Number 5234). 


\section{G. Miscellaneous}

Mahendra, Yusril Ihza, "Bahan Penjelasan Menteri Sekretaris Negara pada Rapat Kerja dengan
Komisi II DPR RI tanggal 25 Januari 2006”, Rapat Kerja Menteri Sekretaris Negara Komisi II DPR RI, Jakarta, January 25, 2006. 